\title{
Energy Planning and Modelling for Gadhinglaj Block using Leap
}

\author{
Nishigandha D. Patil, Ravindra Teli, Ravi Teja, Rahul Hiremath
}

\begin{abstract}
Clean and affordable supply of energy is one of the goals among the 17 sustainable development goals. In developing nations like India the fast development in clean and sustainable energy would allow creating evaluation of the Integrated Sustainable Energy Model scenarios in the context of energy a win-win situation for ensuring the rural energy security, mitigating the impact of rising fossil-fuel cost on the economy and avoid the negative implications of exhausting natural resources and ensure the rural energy security. Therefore, there is substantial scope for the exploitation of renewable energy technologies in bridging this gap by providing affordable and clean energy to the poor to meet their lighting, cooking, and thermal needs. The huge potential for the renewable energy mainly lies in local projects, so there's need to adopt bottomup energy modelling approaches. Energy modelling at block level is highly influential rather than modelling for one village as the block consists of approximately 80-90 villages. Hence the current study emphasizes on energy planning and scenarios modelling for Gadhinglaj block which consists of 93 villages using LongRange Energy Alternatives Planning system (LEAP) tool. The main objective of the study is to develop Integrated Sustainable Energy Model scenarios for Gadhinglaj block also requirement, Social cost and benefit, and their environmental impact. Survey method is used to collect the data. The main output of this research is the development of alternative renewable energy options under different conditions for Gadhinglaj up to 2030.
\end{abstract}

KeyWords: Energy Demand -Supply Model, Energy Infrastructure, Social Implications.

\section{INTRODUCTION}

Nowadays in modern world energy has become a determinant factor to raise the living standard and high lifestyle of people of any country. The energy consumption in developing nations is very low than the energy consumption in developed worlds. This indicates that there is strong relation between per capita energy consumption and Human Development Index (HDI) hence India is continuously aiming towards increasing the per capita

Revised Manuscript Received on September 10, 2019.

Miss. Nishigandha D. Patil, PhD Research Scholar, School of Commerce and Management, Yashwantrao Chavan Maharashtra Open University, Nashik India

(Email: patil.nishigandha6@gmail.com)

Dr. Ravindra Teli, Professor of Commerce and Management, Shivraj College, Gadhinglaj, affiliated to Shivaji University, Kolhapur Maharashtra, India.

(Email: ravindra.teli@rediffmail.com)

Mr. Ravi Teja Ph. D. Research Scholar Symbiosis Center for Management and Human Resource Development, Pune India (Email:ravi_teja@scmhrd.edu)

Rahul Hiremath, Professor, Symbiosis Center for Management and Human Resource Development, SIU Pune India

(Email:rahul_hiremath@scmhrd.edu) energy consumption despite the main agenda of development has been abolition of poverty.

Almost Nearly more than 30 crore population in India is not having access to electricity and about 50 crores are taking root nowadays. The availability of modern energy is very much essential for the overall development of society at all the levels from fulfilling the basic human needs to all the economic activities of modern society[1], that is why energy is considered as an important link that connects society, environment and economic development. [2] Hence access to clean and modern energy is a major driver for the human development [3]. The lack of clean and resilient energy can be a barrier to domestic and industrial sector to stay away from subsistence economy and eliminating poverty. [4]. still using traditional fuel for cooking by rural people. The above figures show that there is still long way to go in order to achieve energy security. Though India is moving towards economic growth and development through GDP rate and National income but still providing clean energy to all needs to be included in poverty alleviation programmes. For a country like India and other developing world's energy access, energy intensity, climate justice, energy poverty, energy security and sustainable development are prime issues which are

However, over 1.1 billion across the globe still lack access to electricity, and 2.9 billion population uses solid fuels like coke and firewood to fulfil their cooking energy needs which produces toxic smoke and pollutants harmful to health and environment. [5], in addition, to this the expansion in population with energy access in the world is struggling to keep up with overall population growth. In fact, even though projections by the International Energy Agency (IEA) expect 1.7 billion people to gain access to electricity by 2030, around 950 million people will still lack electricity access by then the projections given by International Energy Agency [6]. To support energy development, the United Nations (UN) launched the Sustainable Energy for All (SE4All) initiative (2012) [7]. The goals of the SE4All initiative are to achieve universal access to electricity and other safe household fuels, a doubled rate of improvement in energy efficiency, and a doubled share of renewable energy in the global energy mix by 2030. Additionally, Sustainable Development Goal number 7 (SDG7) is to 'ensure access to affordable, reliable, sustainable and modern energy for all' [8]. In line with those goals, governments in energy poor countries are setting ambitious energy targets for their energy access plans.

Published By:

Blue Eyes Intelligence Engineering

\& Sciences Publication 
However insufficient financial resources, lack of effective planning and rapid population growth are just some of the many challenges to achieving these goals.

\section{OBJECTIVES}

The main objective of this research was to develop Integrated Sustainable Energy Model scenarios for Gadhinglaj block upto 2030 by using Long Term Energy Alternative Planning [LEAP] tool In the later part of the study the evaluation of the Sustainable Energy scenarios developed in the context of energy requirement, Social cost and benefit, and their environmental impact was done.

\section{HYPOTHESES OF STUDY}

Following are the hypotheses undertaken for the study in order to achieve the above mentioned objectives.

1. There is possibility of developing sustainable energy modelling scenarios with the use of long-term energy alternative planning tool and to evaluate the scenarios from socio-economic and environmental context.

2. The sustainable energy modelling scenarios developed for Gadhinglaj meet the future energy demand through renewable and bio energy.

\section{REVIEW OF LITERATURE}

The energy planning and modelling is very crucial step while developing policies for the developing nations in order to achieve sustainable development. It is necessary to review the existing work done on energy planning and modelling. Energy plan is one of the pillars for developing policies for sustainable development of a country. According to the Thery and Zarate [2009] energy planning is defined as the supply of energy to meet the given demand by making use of to optimal combination of energy sources. to satisfy a given demand. Multicriteria objective programming was used in which economic, social and technical criterion along with environmental impact was taken for consideration, similarly as per suggestions of Cormio et al. [2003] the important factor to satisfy the future energy demand for that given period of time by analyzing the political, social, and environmental implications. Whereas Hiremath et al. [2007] briefly stated that energy planning is about to find a matching set of energy supply sources with its conversion technologies to meet the energy needs. Energy models have been extensively developed subsequently after the first oil crisis in the 1970s. Jebaraj and Iniyan [2006] have presented a broad review of how energy planning models, forecasting models, energy supply-demand models, optimization models and carbon emission reduction models has progressed over the time. Thus the energy models can be employed as per the approach adopted for analytical, optimization, simulation, linear programming, mixed integer programming, and dynamic programming or multiobjective programming broadly divided into top down and bottom up as per the approach of study similarly it can be classified on the basis of purpose of modelling for instance back casting and forecasting, indentifying supply sources and analysis, it also depends on the time period like short term, medium, long term, and geographical scope(i.e., local, national, regional, and global) (Van beeck, 2003; Nakata, 2011) for energy studies under taken. Nowadays computer aided tools are also used largely for energy modelling and scenario analysis due to its less data needs easy to use and high reliability. Thus intention of the present study is to bridge the gap existing in the literature of energy modelling approaches and selection of suitable model for the energy demand forecasting and scenario analysis.

\section{METHODOLOGY}

The current study is conducted using Long Term Energy Alternative Planning (LEAP) a computer aided tool. LEAP was first developed in 1980 to provide a flexible tool for long-range integration energy planning for the Beijar Institute's Kenya fuel wood project later it was developed by the Stockholm Environment Institute (SEI-US), mostly by considering the needs of developing nations because there is significant difference between the energy consumption pattern of developed countries and developing countries located in Boston, Massachusetts 3. LEAP is a widely used energy modelling tool among various countries of the world as it systematically analyses the present energy demand, forecast future energy demand also indentifies indigenous energy supply sources to meet the future energy requirements(Bautista, 2012; Shin et al., 2005; McPherson and Karney, 2014). It also involves estimation of green house gas emissions and climate change mitigation. LEAP can be useful at different levels from cities and states to national, regional and global applications (Suganthi and Samuel, 2012). Hence the researcher has advantage to use for both top down approach and bottom-up approach. In the current research bottom-up approach is used as decentralized energy planning and modelling of Gadhinglaj block is was taken for study. It takes into account the energy needs and generates various scenarios from context of social acceptance, maximizing use of renewable energy, use energy efficient technologies, energy environment linkages and socioeconomic conditions of people. Hence this is simple scenario tools leads to energy policy analysis. The LEAP tool was used to carry out the present study over many other software tools as it has many advantages like a) it can be used for decentralized level, b) it user friendly and requires data inputs like households, population, GDP etc, c) it is customized one deliberately for the developing countries with their energy needs and availability of conversion technologies. so that both energy demand and its social and environmental implications can be assessed in the same stage d) it consist of a Technology and Environment Database (TED), which collect technical standards required and environmental impacts for variety of energy technologies, including both advanced technologies for developed countries and conventional technologies often found in developing countries and most important feature is it is free for the students, researchers and government bodies from developing worlds. Therefore, LEAP is chosen in this analysis as the best tool for assessing the current energy patterns and for simulating alternative energy futures 
along with greenhouse gas emissions to test the predefined hypotheses for the period 2010-2030. To collect the data regarding the energy consumption and identification of local energy supply sources survey method was used by conducting energy consumption survey among the selected sample villages in Gadhinglaj block in which questionnaire was formulated. The population size is 53000 households approximately thus using Cochran's formula with the level of significance equal to $0.025(\mathrm{Z}=5.02)$ and margin of error $\mathrm{E}=0.05$ we get sample size $\mathrm{n}=498$. Therefore sample size 501 has taken which is greater than the required sample size 498. There are 7 circles in the study area and circle consists of a $12-15$ villages. Hence $10 \%$ villages approximately from each circle purposively (as per the energy demand supply potential) were taken for the survey. Further from each of the selected villages $10 \%$ simple random sample was drawn to get overall sample size $n=501$. Besides this data the animal census data or electricity consumption data, solar and wind energy mapping data, number of biogas plants installed in each village, total land, cropped land, total fallow land, and crop productivity ration data was collected from secondary sources.

\section{STUDY AREA}

The Gadhinglaj block is in Kolhapur district of Maharashtra. It is one among the 12 blocks of Kolhapur district. It is located on borders of two states i.e. Maharashtra and Karnataka. The block has 93 villages and there are total 52,872 households in this Block. As per the Census report of 2011 the total population of Gadhinglaj is 2, 25,734 and total area of Gadhinglaj is $472 \mathrm{~km}^{2}$ including $469.00 \mathrm{~km}^{2}$ rural area and $3.38 \mathrm{~km}^{2}$ urban area. The chief livelihood of the people of Gadhinglaj is agriculture and allied activities like animal husbandry and poultry farming. About $77.5 \%$ of the total population is engaged in agriculture. The main crops like Jowar, Bajra, Wheat and Maize and pulses like Kidney beans, lentils and Bengal gram are gown in this block. Sugarcane is the main cash crops in the block. The net cropped area of the block has been declining gradually and there has been an increase decline in the area under fallows as per the census report 2011. Gadhinglaj is rapidly growing city is the third largest in the Kolhapur District, out of total population approximately $80 \%$ people resides in rural region. So rural energy is considered to be a large part of the energy sector and hence the planning process does not allocate enough space to it. The fact that the potential for the transition towards renewable energy is mainly based in local projects, so there's need for Decentralized sustainable energy planning for sustainable energy development at Block level. Thus, this research intends to study the need for implementation of integrated sustainable energy planning and modelling for Gadhinglaj Block of Kolhapur district.
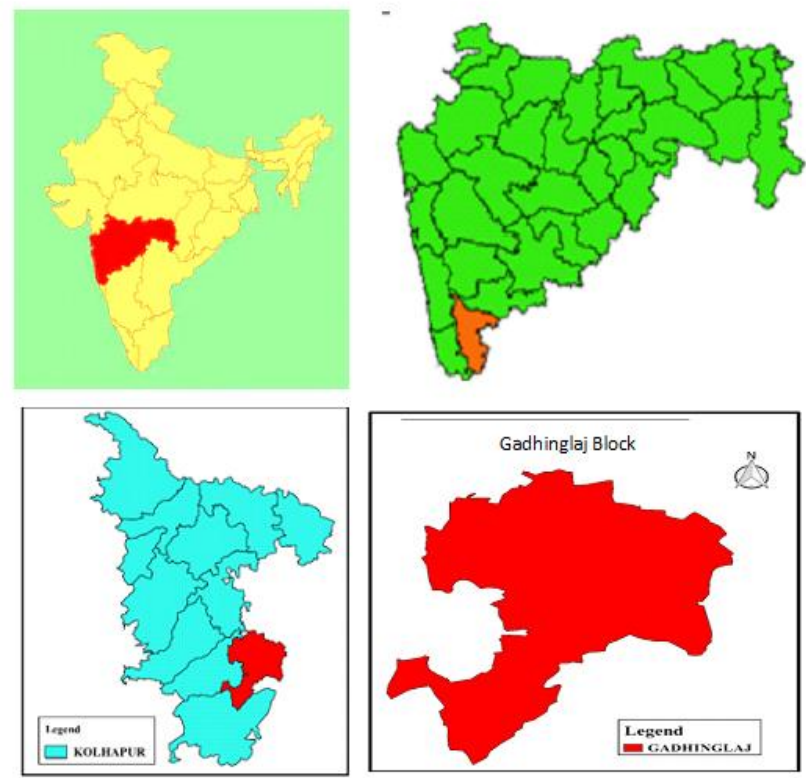

Fig. 1.Study Area Map

\section{CURRENT ENERGY SCENARIO OF GADHINGLAJ BLOCK}

In Gadhinglaj block $80 \%$ population resides in villages whereas $20 \%$ population in Gadhinglaj city. Thus cooking activity accounts $70 \%$ of total energy use in which biomass is used as fuel for cooking for about $\%$ people. Three stone cook stoves are used for cooking which has very low thermal efficiency i.e $5 \%$ and $10 \%$ (Jargstrof B., 2004). After the launching of Ujjwala scheme the villagers are now using L.P.G for cooking instead of kerosene stoves. Hence the use of kerosene is declined drastically over a period of time due to availability of LPG stove from the government. Biomass is still being used for water heating accounted for $40 \%$ of total energy consumption in Gadhinglaj, whereas for home lighting electricity through grid is used because Gadhinglaj block is $100 \%$ electrified. Solar lamps are also used for public lighting. The total energy consumed in these rural industries like sugar factory, poultry, milk processing rice mill, oil mill, cashew processing units, brick making, cottage industries like flour mills, is about 19,640 GJ/year.

\section{Energy share}

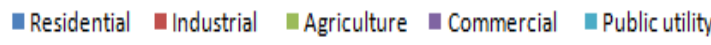

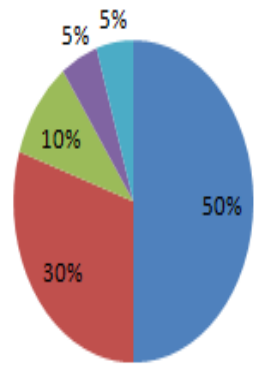

Fig. 2. Percent energy use in different sector in Gadhinglaj block 


\section{LOCAL ENERGY SUPPLY SOURCES IN GADHINGLAJ BLOCK}

Gadhinglaj has rich potential in biomass resources like Woody biomass which consists parts of branches and trunks either whole or split, leaves fallen litter and foliage, crop residues from cereal, pulses and oil crops like groundnuts and sunflower, dried dung (normally cattle dung), most commonly mixed with soil and grass to form "dung cakes"

which are used for cooking and water heating. Then sugar industry waste bagasse residues obtained from sugarcane stalks after juice extraction and rice or paddy husks from rice mills can be used as Briquette by sugar industry and other food processing industries. Oil cakes can be produced from the processed oil seeds from oil mill and used as a source of fuel.

Table I End use energy efficiencies (\%)

\begin{tabular}{|clc|}
\hline & Name of Energy & \\
Sr.No & Source & Energy efficiency \\
\hline 1 & Dung cake & $\mathbf{1}$ \\
2 & Firewood & 10 \\
3 & Farm residue & \\
4 & Kerosene & 31 \\
5 & LPG & 45 \\
6 & Biogas & 43 \\
7 & Solar thermal & 20 \\
8 & Diesel electricity & 22 \\
10 & Electricity (grid) & 23 \\
11 & Biomass electricity & 15 \\
12 & PV electricity & 10 \\
13 & Biogas electricity & 19 \\
\hline & & \\
\hline
\end{tabular}

Table II. Cost of fuel for end-use activities (Rs/kWh).

\begin{tabular}{|c|c|c|c|c|c|c|c|}
\hline Sr.No & $\begin{array}{l}\text { Name of } \\
\text { energy } \\
\text { source }\end{array}$ & $\begin{array}{l}\text { Residential } \\
\text { (Cooking) }\end{array}$ & $\begin{array}{l}\text { Residential } \\
\text { (Home } \\
\text { lighting) }\end{array}$ & Agriculture & $\begin{array}{l}\text { Residential } \\
\text { (Water } \\
\text { heating) }\end{array}$ & Industrial & $\begin{array}{c}\text { Residential } \\
\text { (Home } \\
\text { appliances) }\end{array}$ \\
\hline & Dung & 0.6 & & & & & \\
\hline 1 & cake & & - & - & 0.31 & - & - \\
\hline 2 & Firewood & 0.9 & - & - & 0.9 & - & - \\
\hline & Farm & 1.2 & & & & & \\
\hline 3 & residue & & - & - & 1.2 & - & - \\
\hline 4 & Kerosene & 0.82 & 0.82 & - & 0.82 & - & - \\
\hline 5 & LPG & 1.71 & - & - & 1.71 & - & - \\
\hline 6 & Biogas & 0.27 & 0.27 & - & 0.27 & - & - \\
\hline & Solar & 0.37 & & & & & \\
\hline 7 & $\begin{array}{l}\text { thermal } \\
\text { Diesel }\end{array}$ & - & - & -1 & 0.27 & - & - \\
\hline 8 & $\begin{array}{l}\text { electricity } \\
\text { Electricity }\end{array}$ & 4.5 & 18 & 18 & 18 & 18 & 18 \\
\hline 10 & $\begin{array}{l}\text { (grid) } \\
\text { Biomass }\end{array}$ & 6 & 4.5 & 1 & 4.5 & 6.5 & 4.5 \\
\hline 11 & $\begin{array}{l}\text { electricity } \\
\text { PV }\end{array}$ & 8 & 6 & 6 & 6 & 5 & 6 \\
\hline 12 & $\begin{array}{l}\text { electricity } \\
\text { Biogas }\end{array}$ & 4 & 8 & 8 & 8 & 8 & 8 \\
\hline 13 & electricity & & 4 & 4 & 4 & 4 & 4 \\
\hline
\end{tabular}


Table III. Environmental emissions of different fuels.

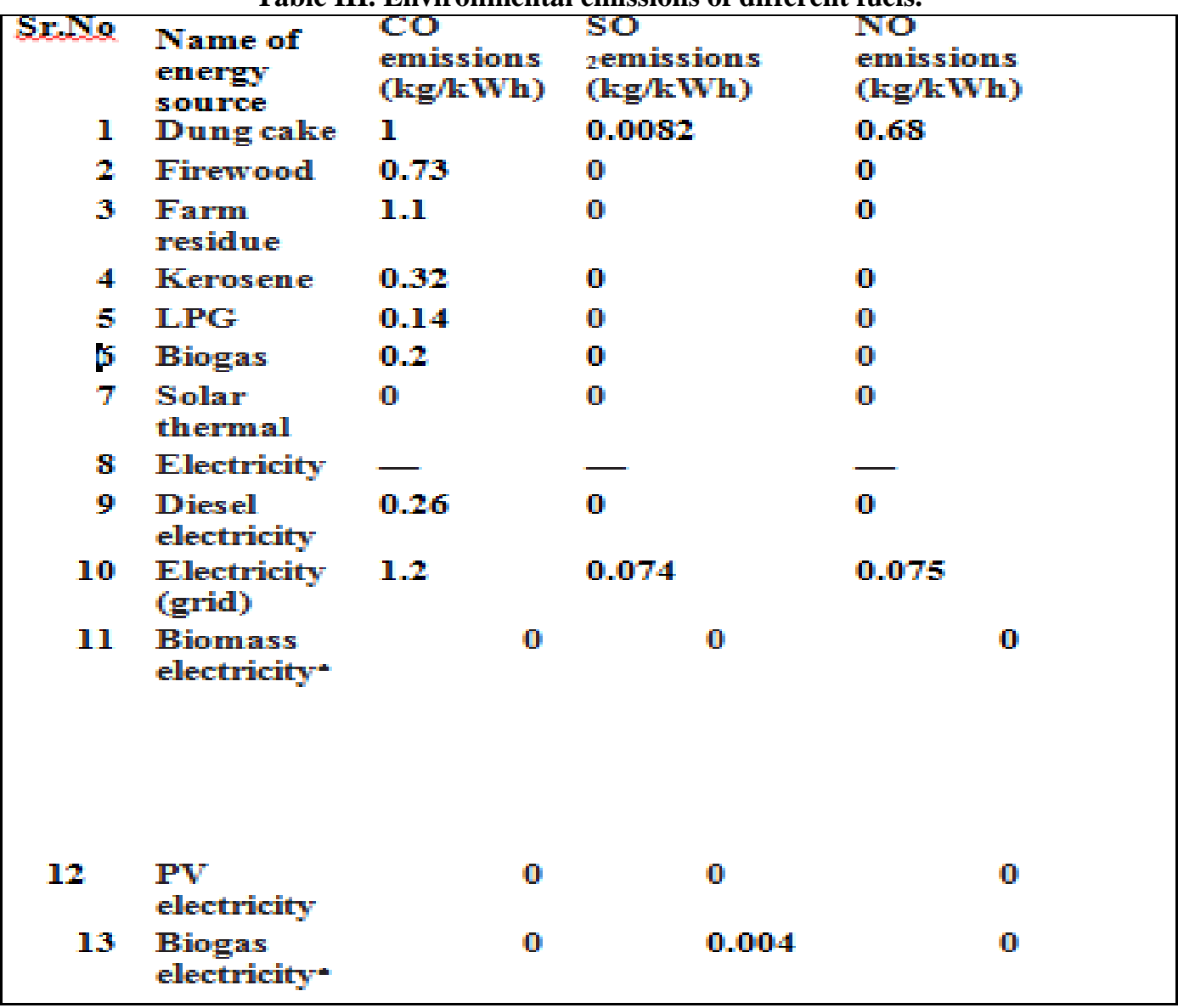

\section{SCENARIO CONSTRUCTION}

Scenario construction involves the identification of alternative energy supply sources under various assumptions considered, forecasting the energy demand for the assumed time horizon. As per the characteristics and the parameters of the assumptions are inserted in LEAP tool and the future energy pathways were analyzed under the specific scenarios. Later on the analyzed scenarios are evaluated qualitatively and quantitatively on the aspects like Social implications, political issues and economic development, Energy diversity Advanced technologies and $\mathrm{CO}_{2}$ emissions.

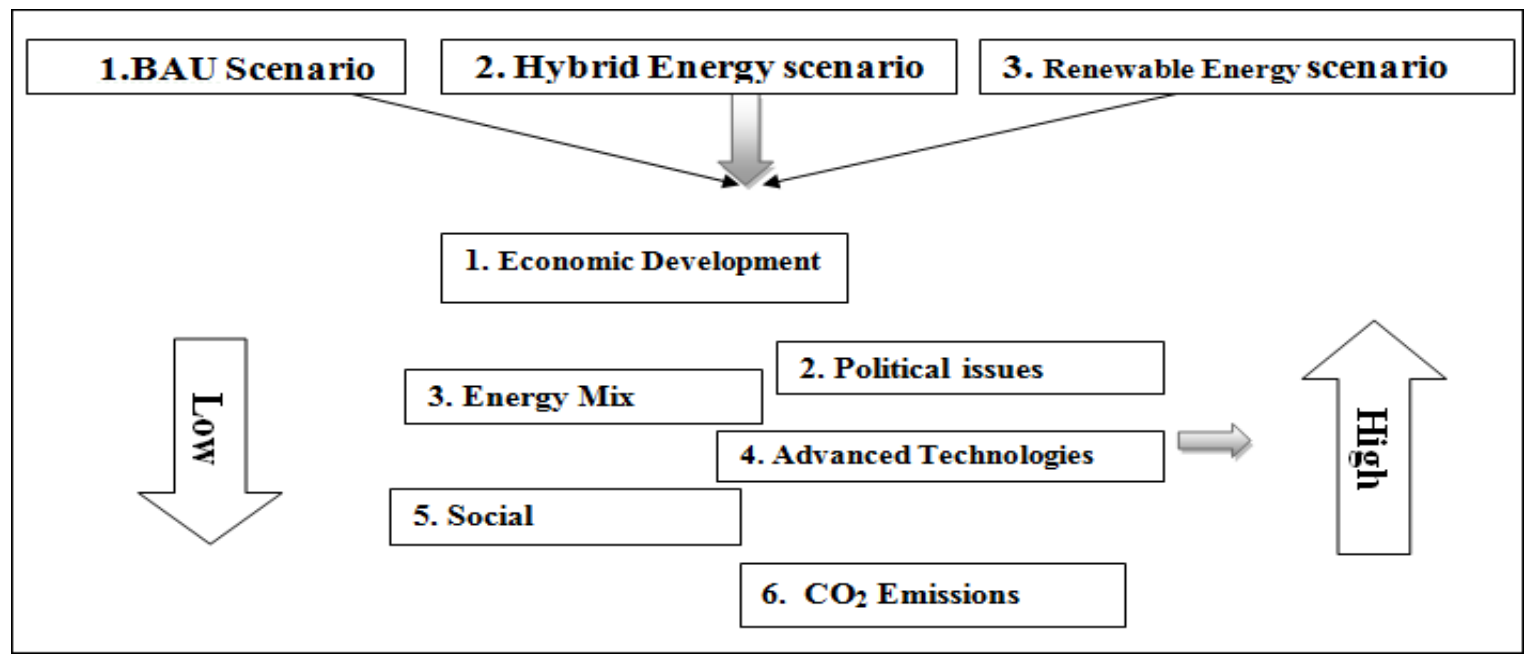

Fig. 3: Key Scenarios Variables

Three scenarios were constructed and developed on the basis of assumptions and targets considered as alternative long term energy pathways for Gadhinglaj block.

1. The Business As Usual scenario (BAU): 
In this scenario it is assumed that restrained economic growth, with no change in energy consumption pattern, no technological advancement, no cleaner production with as usual environmental impacts due to heavy reliance on carbon intensive fuels resulting in very high carbon emissions and social implications

\section{Hybrid Energy Scenario (HES):}

In this scenario optimum use of renewable and non renewable energy sources, a combination of energy mix is used along with moderate technological advancement and moderate economic growth sing on reducing environmental impacts and emissions by promoting clean and affordable energy supply.

3. Renewable Energy Scenario (RES):

This scenario mainly addresses the promotion and use of renewable energy sources and eliminating the use of fossil fuels and other traditional energy sources. This is done by increasing energy efficiency also making $100 \%$ use of renewable energy. High reliance on renewable energy promotes sustainable development but do not acknowledge the concept of equity and social acceptance resulting many social implications and political issues in implementation of the scenario.

\section{RESULTS AND DISCUSSION}

Table. IV Sustainable Energy Scenarios for Gadhinglaj block upto 2030

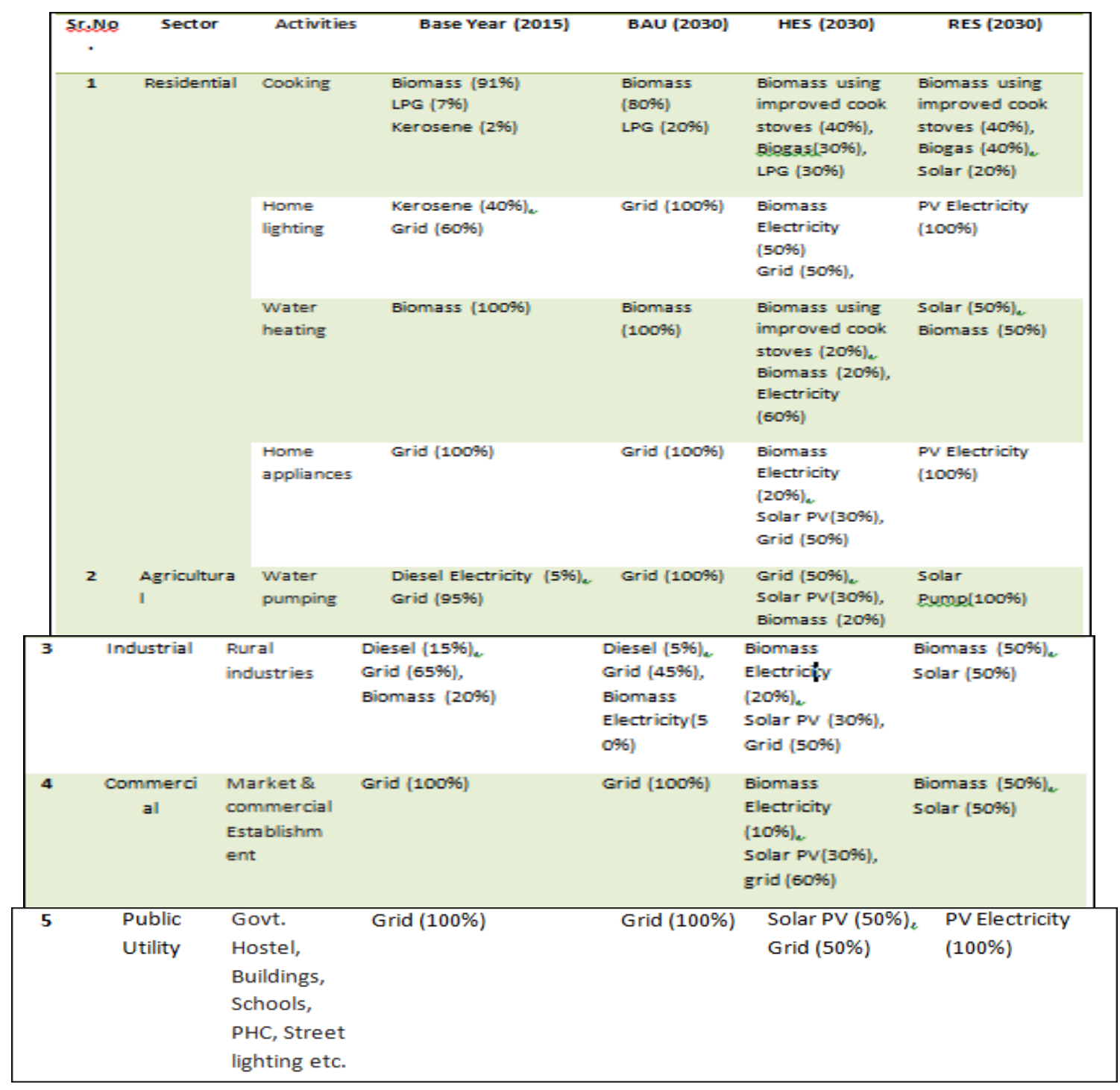


Table. V Gross employment Generation potentials from renewable energy sources

\begin{tabular}{|c|c|c|}
\hline Sr.No & $\begin{array}{l}\text { Energy } \\
\text { resources }\end{array}$ & $\begin{array}{l}\text { No of } \\
\text { employees in } \\
\text { hundreds }\end{array}$ \\
\hline 1 & $\begin{array}{l}\text { Biomass } \\
\text { electricity }\end{array}$ & 700 \\
\hline 2 & $\begin{array}{l}\text { PV } \\
\text { electricity }\end{array}$ & 510 \\
\hline 3 & $\begin{array}{l}\text { Biogas } \\
\text { electricity }\end{array}$ & 575 \\
\hline 4 & $\begin{array}{l}\text { Solar } \\
\text { thermal }\end{array}$ & 525 \\
\hline
\end{tabular}

Above table shows different energy demand and supply combinations under the three predetermined scenarios i.e BAU where no change is with stable growth is expected by using indigenous energy sources like biogas electricity and biomass electricity. The second is hybrid energy scenario where off grid and on grid electricity combinations are used to meet the demand of energy and in the third scenario i.e. renewable energy scenario only off grid renewable energy supply sources are used.

\section{CONCLUSION}

Long term energy alternative planning tool has used bottom up approach as energy planning and modelling is done for Gadhinglaj block of Kolhapur district. The current work has identified and analysed the energy demand and local energy supply sources of Gadhinglaj block and forecasted energy consumption pattern by local energy supply sources by 2030 by using long term energy alternative planning tool. Three Scenarios were constructed for Gadhinglaj block in which first was BAU scenario i.e business as usual scenario second was hybrid energy scenario and third was RES i.e. renewable energy scenario All the three scenarios were analysed for the year 2030, the base year for analysis selected was 2015. The electricity consumption was analysed for last 15 years, under various sectors like residential, industrial, commercial and agriculture. The trend analysis of consumption was further processed to get sector wise distribution among the above five sectors. In Gadhinglaj block, Harali Budruk, Hiralge,Jambhulwadi , Manwad, Karambali are the energy surplus zones as they have high percentage of fallow which can be used for biomass energy plantation also for solar farms. Village like Hitni, Kasba Nool, Kadgaon, Jarali, Huginhal are the high energy demand villages. Thus the electricity demand of Gadhinglaj block residential or household sector can be met by bio energy plantations by using biomass conversion to electricity either by gasification or by electrification. Use of solar heater, solar cooker and biogas should be enhanced to 100 percent in renewable energy scenario to meet the energy needs for cooking activity. Technological advancement like gasification and electrification through biomass gasifier can also increase the use of biomass and biogas to satisfy the cooking energy requirements of block and also village. There is a variation in availability of the cattle dung among the villages, hence the alternative of using biogas in order to meet the cooking energy needs can be vary from house to house. It is not feasible option for the houses with low number of cattle hence collection of cattle dung and installation of community based biogas plants can give better results Thus, optimal energy planning for energy demand and supply from indigenous energy sources is necessary. The LEAP analysis is then evaluated on the socio economic and environmental context. The analysis of three scenarios under LEAP tool showed that there is strong possibility for adopting renewable energy and sustainable energy modelling scenarios to meet the future energy demand of Gadhinglaj in all the five sectors. This will also contribute in job creation in renewable energy also making safe and clean energy usage to all the villagers of Gadhinglaj block. Hence tool analysis showed that the above stated hypotheses are tested and results are accepted

\section{ACKNOWLEDGEMENT}

I would like to express my sincere thanks to our honourable Vice Chancellor Prof.E.Vayunandan for providing opportunity to carry out the research work in Yashwantrao Chavan Maharashtra Open University, I am also grateful to Dr Rahul Hiremath Assistant Professor, Symbiosis Center for Management and Human Resource Development, Pune for his valuable guidance and motivation for this research article.

\section{REFERENCES}

1. https://economictimes.indiatimes.com/news/economy/pol icy/energy-efficiency-need-of-hour-says-nitiaayog/articleshow/57313756.cms

2. Thery R, Zarate P. Energy planning: a multicriteria decision making structure proposal. Cent Eur J Oper Res 2009; 17:265-74.

3. Cormio C, Dicorato M, Minoia A,Trovato M. A regional energy planning methodology including renewable energy sources and environmental constraints. Renew Sustain EnergyRev2003;7:99-130.

4. Hiremath RB, Shikha S, Ravindranath NH. Decentralized energy planning; modeling and application-a review. Renew Sustain Energy Rev 2007;11:729-52.

5. Jebaraj S, Iniyan S. A review of energy models .Renew Sustain Energy Rev a. 2006;10:281-311.

6. Hiremath RB, Kumar B, Balachandra P, Ravindranath $\mathrm{NH}$. Implications of Decentralised energy planning for rural India. J Sustain Energy Environ 2011; 2:31-40.

7. Heaps C. Integrated energy-environment modelling and LEAP.2002. 〈http:// www.unfccc.int〉

8. Zhang D, Liu P, Ma L, Li Z. A multiperiod optimization model for planning of China's power sector with consideration of carbon dioxide mitigation - the importance of continuous and stable carbon mitigation policy. Energy Policy 2013; 58:319-28.

9. Van Beeck, N., 2003. A New Decision Support Method for Local Energy Planning in Developing Countries (Ph.D.). Tilburg University, Tilburg, the Netherlands. World Development Indicators (WDI) 〈www.data.worldbank.org

10. Suganthi L, Jagadeesan TR. A modified model for prediction of India's future energy requirement. Int. J 
Energy Environ 1992; 3:371-86.

\section{AUTHORS PROFILE}

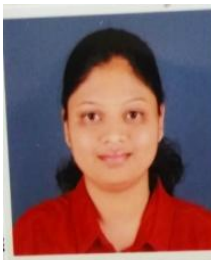

Miss. Nishigandha Patil is currently pursuing full time Phd in Management in Yashwantrao Chavan Maharashtra Open University after completing her M.B.A. with specialization HRM and Environment..She is a full time $\mathrm{PhD}$ research scholar in School of Commerce and Management working under the supervision of Dr Ravindra Teli. Her research area broadly focuses on Sustainable energy management and green HRM.

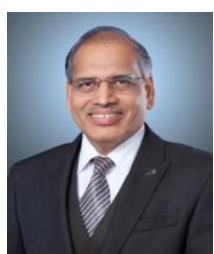

Dr Ravindra Teli has PhDs in Commerce from Shivaji University, Kolhapur. He is working as a professor in Shivraj College, Gadhinglaj. He is having 36 years UG teaching experience and 16 years PG teaching experience. He has completed 3 years article ship of C.A. also acted as internal auditor of Co-op. Societies and worked as an Audit Assistant..He has a recognition as a P. G. teacher in M. Com. ,M. Phil and Ph. D. Course in the 'Commerce and Management' discipline $\mathrm{He}$ has presented paper and written research paper in the area of corporate governance and general management. Financial Accounting, Principles of Marketing, Insurance, Corporate Accounting, Fundamentals of Entrepreneurship, Modern Management Practices, Business Regulatory Framework. 